Mateusz Szast (i) https://orcid.org/0000-0001-5677-6471

\author{
Uniwersytet Pedagogiczny im. KEN w Krakowie
}

\title{
KOMUNIKACJA SPOŁECZNA W PRACY SOCJALNEJ - ASPEKTY TEORETYCZNE I PRAKTYCZNE
}

\author{
Abstract \\ Social communication in social work - theoretical and practical aspects
}

The purpose of the article is to draw attention to the issues not so much as communication, but to communicate in social work, with particular emphasis on the essence of communication between individuals, listening and not hearing and perceiving rather than seeing the needs of other people. Proper intergenerational and intercultural communication, in turn, can condition understanding and empathy by capturing the interlocutor's point of view - it should be noted that the vast majority of social workers are younger than their pupils, characterized by specialized education, which may make it difficult to understand the level of abstraction of their stakeholders or beneficiaries. In the analysis completed with recommendations for social workers, both verbal and non-verbal channels were included.

Keywords: communication, social work, emotional intelligence

\section{Wprowadzenie - zasadność podjęcia problematyki}

Komunikacja interpersonalna to tematyka chętnie podejmowana przez badaczy w obszarach nauk społecznych i humanistycznych, w takich dyscyplinach, jak socjologia, psychologia społeczna, psychologia czy politologia. Jest to zatem tematyka mocno eksploatowana na potrzeby rynku pracy, zarządzania, wykorzystania w rozmaitych poradnikach (które de facto także muszą się sprzedać). Podejmowane są głównie aspekty jej stosowania, skuteczności, sposobów interpretacji, rozwoju technik usprawniających komunikację - wszystko po to, aby rozumieć sens komunikacji, maksymalizować jej użyteczność do realizacji zamierzonych celów.

Autor niniejszego artykułu stawia sobie za cel nieco inne spojrzenie na problematykę komunikacji interpersonalnej. Przedstawione tu tezy ogniskują się wokół komunikacji w pracy socjalnej, właściwego zrozumienia komunikacji interpersonalnej w pracy z człowiekiem, który pomocy wymaga i może nie mieć ekonomicznych potrzeb wartych zaspokojenia. Tekst stawia sobie za cel uchwycenie idei personalistycznej komunikacji, 
nazywanej zamiennie rozmową, dialogiem z drugim człowiekiem, który winien stać się centrum zainteresowania rozmawiających osób. Główne pytanie badawcze brzmi zatem: jakie występują zależności (związki) pomiędzy zrozumieniem istoty komunikowania międzyludzkiego a udzielaniem pomocy osobom potrzebującym? Uznaje się, iż obecny dyskurs poznawczy, nakierowany na pragmatyczne wykorzystywanie komunikowania, zakłada realizację odgórnie założonych celów bez głębokiej refleksji nad potrzebami emocjonalnymi osób w nią uwikłanych.

Jak podają Charles D. Garvin oraz Brett A. Seabury, praca socjalna to działalność, której istotą jest poszukiwanie przez jednostkę sposobów zaspokojenia swoich potrzeb środowiskowych $\mathrm{w}$ reakcjach środowiska na te potrzeby. Funkcja pracownika socjalnego, wkraczającego $\mathrm{w}$ relacje pomiędzy jednostką a środowiskiem, może być spełniona przez redukowanie lub rozwiązywanie problemów, które pojawiły się w obrębie funkcjonowania jednostki; zapobieganie zagrożeniom wynikającym z dysfunkcji reakcji środowisko - jednostka lub zasilanie ludzkiego potencjału w taki sposób, by umożliwić jednostce satysfakcjonujące życie w środowisku społecznym. Należy nadmienić, iż poprawienie warunków lub rozwiązywanie problemów jednostki może być realizowane przez wzbogacanie zdolności do ich rozwiązywania przy wykorzystaniu zasobów własnych (np. kapitału ludzkiego), pomaganie ludziom w radzeniu sobie z problemami środowiskowymi oraz rozwijanie ich potencjału twórczego (obecnie powiedzielibyśmy - kreatywności), a także promocję odpowiedzialnych, efektywnych i humanitarnych sposobów działania przy włączeniu ludzi w systemy, które dostarczają im środków, usług oraz szans rozwojowych (Garvin, Seabury 1998a: 30). Profesjonalna praktyka w pracy socjalnej (nazwanej przez autorów także profesją) wskazuje na kluczowe elementy: wiedzę, wartości oraz działań zgodnych z wiedzą i wartościami. Działania te w pracy socjalnej nazywane są repertuarem środków interwencyjnych (Garvin, Seabury 1998a: 48) w obrębie relacji pracownik socjalny - podopieczny. W świetle przedstawionych założeń zasadność podjęcia tematyki komunikacji jako podstawy pracy socjalnej nie powinna budzić wątpliwości.

\section{Komunikacja społeczna - aspekty podstawowe}

Pojęcie komunikowania pochodzi od łacińskiego słowa comunico, comunicare (uczynić, połączyć, udzielić). Obecnie odnosi się do kalki językowej z języka angielskiego communication i oznacza łączność. Do XVI wieku pojęcie komunikowania funkcjonowało w znaczeniu komunii, uczestnictwa czy dzielenia, by później zyskać drugie znaczenie - transmisji i przekazu, co z kolei miało związek z rozwojem poczty oraz dróg. Takie rozumienie nabrało wagi zwłaszcza w XIX i XX wieku ze względu na dynamiczny rozwój mediów, prasy oraz nasilenie zjawiska przemieszczania się ludzi, dlatego dla jednych termin ten oznacza porozumiewanie się z innymi, a dla innych transport. Jest to termin pojemny (Buller 2008: 28). Komunikacja jest zatem procesem, dynamicznym, zmieniającym się i rozwijającym, w którym nadawca jest jednocześnie odbiorcą, a odbiorca nadawcą i to 
właśnie obie strony są odpowiedzialne za przebieg komunikacji - warto sprawdzać, czy przekaz jest podobnie rozumiany. Spora część komunikacji między ludźmi odbywa się nieświadomie, gdyż większy udział w odczytywaniu znaczenia komunikatu mają sygnały niewerbalne niż treściowe (Buller 2008: 31). Komunikacja interpersonalna jest to spontaniczna, ludzka, nieformalna i pierwotna forma kontaktu, która obejmuje szereg uwarunkowań psychologicznych, kulturowych, korzysta z wielu środków ekspresji, postawy, mimiki, gestów i tym podobnych. Kolejny rodzaj komunikacji to komunikacja specyficznie społeczna, zwana komunikacją w organizacji, która występuje tam, gdzie mamy do czynienia z zamkniętą strukturą i umożliwia jej funkcjonowanie (instytucje publiczne, organizacje, przedsiębiorstwa). Z kolei komunikacja masowa, zwana inaczej medialną lub komunikacją społeczną, utrzymana jest dzięki prasie, telewizji i innym nowoczesnym mediom (Buller 2008: 32).

Podstawowy model komunikowania obejmuje nadawcę, kodującego komunikat przesyłany do odbiorcy, który ten komunikat odkodowuje (ujęcie Winfrieda Schulza), w ramach pewnego kanału komunikacyjnego i kontekstu sytuacyjnego. Istotne są także wszelkiego rodzaju szumy komunikacyjne oraz sprzężenie zwrotne komunikatu, utwierdzające nadawcę w przekonaniu, iż został właściwie zrozumiany (Pisarek 2008: 22-356). Stanowi ona także wymianę doświadczeń oraz wspólne działanie. Stefan Frydrychowicz podaje wymiary komunikacji: przekazywania informacji, przekazywania emocji/energii, wspólnego wykonywania "czegoś”, współuczestniczenia i ustalania relacji. Autor używa terminu „wymiar”, a nie „funkcja”, ponieważ „wskazuje na ważne płaszczyzny, które powinny zawierać się w komunikacji, aby komunikacja była pełna i tym samym efektywna. Natomiast mówiąc o funkcjach komunikacji, mamy na myśli to, co umożliwia komunikacja osobom komunikującym się" (Frydrychowicz 2005: 95).

\section{Znaczenie komunikacji interpersonalnej w pracy socjalnej}

Niezależnie od tego, jaki model pracy względem osoby lub grupy osób pracownik socjalny obierze, wskazać należy na tło jego pracy oraz modele praktyki. Wyróżnia się w tym zakresie procedury ukierunkowane na: poznanie, zachowanie klienta oraz emocje. Gwoli ścisłości należy również wspomnieć o procedurach pracy socjalnej z rodziną lub grupą jako systemem działania, tu wymienia się procedury modyfikowania: sferę poznawczą, uczuć czy zachowań klienta. Autorzy wyliczają też procedury związane ze środowiskiem, a więc sieciami więzi społecznych, konsultacjami społecznymi czy facylitacji zasobów ludzkich (Garvin, Seabury 1998b: 15-57).

Komunikacja interpersonalna w pracy socjalnej to tematyka ważna z co najmniej dwóch powodów. Po pierwsze, pracownik socjalny (a także inni profesjonaliści bezpośrednio współpracujący z ludźmi w potrzebie) to osoba, która powinna charakteryzować się właściwym sposobem komunikowania (dialogu), by w sposób najbardziej odpowiedni zrozumieć problem, z którym zwraca się do niego podopieczny. Po drugie, 
osoba pracująca z innymi ludźmi (podopiecznymi) musi cechować się motywacją (wolą) do zrozumienia drugiego człowieka ( $w$ tym przypadku człowieka $\mathrm{w}$ potrzebie) z zachowaniem zarówno jego, jak i swojej godności, delikatności oraz poszanowaniem praw ludzkich. Realizacja wymienionych postulatów jest konieczna w trakcie niesienia pomocy bliźniemu, ale jest także trudna i wymaga od specjalisty z zakresu pracy socjalnej zaangażowania.

Jest to trudne, ponieważ obecnie zauważa się chęć posiadania przez ludzi umiejętności miękkich, które mogą być rozwijane dzięki rozmaitym szkoleniom, kursom (nawet internetowym) czy studiom specjalistycznym. Specjalistycznym, gdyż nauka się specjalizuje - wszystko po to, aby człowiek mógł ją wykorzystywać w konkretnym celu. W przypadku komunikacji międzyludzkiej chodzi o trzy zasadnicze cele komunikowania:

1. nawiązanie kontaktu, co jest najtrudniejsze (kontakt);

2. uzyskanie wiarygodności (wiarygodność);

3. osiągnięcie sprawności, aby powiedzieć, co się chce powiedzieć (sprawność).

Znany specjalista języka polskiego, profesor Jerzy Bralczyk, wskazuje, iż mówienie, zwane inaczej sztuką, ma brzydki (negatywny) przymiotnik - „sztuczny”, określający doskonalenie w sztuce jako kształcenie właściwych i skutecznych sposobów mówienia (komunikowania), a także człowieka o wykształconej umiejętności (sztuki) mówienia. Jak powiada Bralczyk:

Jeśli mamy do czynienia ze sztuką, to i sztuczność się czai, jeżeli postrzegają państwo kogoś, kto widać, że posiadł sztukę mówienia, to oceniają go państwo jako mało naturalnego. Wiarygodność jego może nawet spaść. Czy lubimy słuchać kogoś, kto umie przemawiać? Orator, mówimy. Retor, krasomówca - w tych wszystkich słowach jest jakaś ironia... ciągle ważne jest, że jeżeli człowiek mówi zbyt dobrze, to określamy go, że źle działa, bywa określany mistrzem, mistrzem przekonywania (...). Jeżeli się nad tym zastanowię, to wolałbym, żeby przekonywał mnie ktoś, kto przekonywać nie umie, ponieważ wtedy będą jego racje (merytoryka), a nie kunszt ${ }^{1}$.

Anna Krajewska uważa podobnie, twierdząc, że:

Sztuka porozumiewania się to jedna z podstawowych umiejętności życiowych. Od niej zależy, jak szybko, sprawnie i poprawnie dogadujesz się z innymi. Od pierwszych tygodni życia człowiek zaczyna dostrzegać obecność drugiej osoby i próbuje nawiązać kontakt, najpierw z matką, później obojgiem rodziców, opiekunami. Jako noworodek jest całkowicie zależny od innych. W miarę upływu czasu człowiek rozwija się, rośnie dojrzewa, usamodzielnia się. Jednak przez cały czas funkcjonuje wśród innych ludzi. Porozumiewa się z nimi przez całe życie (Krajewska 2018: 19).

1 Wykład Jerzego Bralczyka, wygłoszony 3 kwietnia 2017 roku w pt. „Jak mówić, żeby nas słuchano?” w ramach cyklu „Wielkie pytania w nauce”, organizowanego przez Wyższą Szkołę Informatyki i Zarządzania w Rzeszowie we współpracy z „Tygodnikiem Powszechnym”. 


\subsection{Zagadnienia aktywnego słuchania w pracy z ludźmi w potrzebie}

Słuchanie i słyszenie - to terminy znane, ale nie do końca właściwie rozumiane przez opinię publiczną, a istotne w przypadku pracy z człowiekiem. Otóż pierwsze pojęcie dotyczy sytuacji, w której interlokutorzy czynnie, aktywnie podejmują dialog, który polega na poszukiwaniu informacji, pogłębienia więzi i zrozumienia pomiędzy nimi. By prawidłowo słuchać należy zwrócić uwagę na kilka czynników. Po pierwsze, należy pokazywać bez słów zrozumienie przekazu (używanie zachęcających zwrotów, tj. tonu głosu (popularne „hmmm”), podtrzymujących rozmowę i świadczących zarazem o pilnym słuchaniu). Po drugie, można przyjąć punkt widzenia rozmówcy (empatia, „wejście w skórę"). Po trzecie, należy wykazać otwartość na inny niż własny punkt widzenia, szczególnie w sytuacji, gdy poglądy rozmówców znacznie się różnią, oraz skoncentrować uwagę na tym, co rozmówca ma do powiedzenia i nie przeszkadzać mu w żaden sposób. Po czwarte, ważny jest kontakt wzrokowy (30-60\% czasu rozmowy) oraz pochylenie, wskazujące na zainteresowanie (pochylamy się nad tematem/problemem) - lekkie, w stronę osoby, której słuchamy, bez naruszania jej obszaru prywatności. Ważne jest, aby powstrzymać się od ocen, wyrażania własnej opinii przed dokładnym zrozumieniem treści komunikatu i intencji jego nadawcy oraz by robić przerwy (sprawdza się technika ciszy), nie przerywać i docenić rozmówcę. Drugie sformułowanie (słuchanie) odnosi się do procesu biernego odbioru dźwięku i słów (Buller 2005: 57). Zatem słyszenie to nie to samo co słuchanie "nieświadome", słuchanie „pozorne". Słuchanie aktywne jest umiejętnością odróżniającą osoby potrafiące się komunikować od tych, które tej zdolności nie posiadają. Tę umiejętność charakteryzuje sprawdzanie poziomu zrozumienia, umożliwienie nieskrępowanej wypowiedzi w godnych warunkach, przy fizycznej orientacji na rozmówcę w kontakcie i z szacunkiem (Krajewska 2018: 28).

Obecnie częściej wspomina się nie o mówieniu, a o komunikowaniu, co przekłada się na wypracowanie rozmaitych metod czy technik właściwego (sprawnego) komunikowania. Nastawienie na celowość i skuteczność sprawia, iż człowiek w mniejszym stopniu czerpie satysfakcję z mówienia i bycia ze sobą nawzajem w trakcie rozmowy. Jest tak, ponieważ rozmowy częściej się obecnie przeprowadza, niż prowadzi. Kontakty są udane (celem jest bycie ze sobą), a nie skuteczne. Mówienie jest pracą, walką, mówimy, by przekonać... mówimy, by wypełniać rytuały. Profesor Jerzy Bralczyk powiada, że:

Starożytni Grecy w swojej poczciwości przyjęli, że retoryka to wspólne dla mówiącego i słuchającego dążenie do prawdy. Dla mnie to raczej postulat. Rzymianie definiowali, że retor to mąż prawy, przygotowany do mówienia. A generalnie przez stulecia retoryka nie miała dobrej sławy. I słusznie podkreślano, że kiedy obok siebie postawimy nagą prawdę i nagie kłamstwo, to jedno od drugiego odróżnimy bez trudu. A kiedy pięknie ubiorą się w słowa, to bywają nie do odróżnienia. I dlatego retoryka często była postrzegana jako umiejętność zwodnicza. Mało tego: w rozumieniu potocznym człowiek, który pięknie mówi, postrzegany jest jako ten, który czyni trochę gorzej. Nie ma uniwersalnej metody, która odpowiedziałaby na pytanie: jak mówić, żeby nas słuchano. I w dodatku tak 
mówić, żeby przekonać. I bardzo dobrze, że nie ma takiej metody, bo gdyby znano odpowiedź na takie pytanie, to władaliby nami manipulatorzy, którzy by taką wiedzę posiedli (Plęs 2019).

Funkcją komunikacji interpersonalnej jest porozumiewanie się, a jej wynikiem porozumienie. Anna Krajewska wylicza następujące elementy tego zjawiska:

1. komunikacja jest procesem niepowtarzalnym,

2. komunikacja jest oparta na systemie kodów,

3. komunikacja jest procesem złożonym, ciągłym i niepowtarzalnym, zachodzi bowiem w otoczeniu społecznym (Krajewska 2018: 21).

Składają się na nią:

1. kontekst,

2. intencje,

3. uczestnicy,

4. kodowanie,

5. przekaz,

6. odbiór,

7. odkodowanie,

8. sprzężenie zwrotne,

9. szumy informacyjne,

10. bariery (Krajewska 2018: 23).

\subsection{Aspekty komunikacji niewerbalnej w pracy z ludźmi w potrzebie}

Przez narastający pośpiech i wymogi formalne wykonywania obowiązków służbowych zauważa się traktowanie człowieka jako sprawy, celu, problemu. Sprawia to wrażenie „sztywności” relacji. Ludzie porozumiewają się nie tylko słowami, ale także głosem i gestem. W procesie komunikowania się istotą jest również sytuacja komunikujących się osób, gdyż celem jest zarówno przekazanie tego, co mamy przekazać, jak i nawiązanie kontaktu. W tym przypadku należy wskazać na istotną zasadę, by mówić ludziom, a nie do ludzi. Mówimy w sposób wiarygodny, to cecha osoby mówiącej, która może być przypisana przez słuchających, jeśli postrzegają mówiącego jako wiarygodnego i kompetentnego. Pomiędzy językiem a myślą jest głos. Sztuczność głosu także ma wpływ na odbiór przekazu. Związek myśli i głosu w naturalny sposób wpływa na jego wiarygodność. Gesty, mimika sumują się i jako mniej konwencjonalne uchodzą za bardziej prawdziwe. Ważne jest, czy ludzie mówią wolno, czy szybko (szybka mowa prowokuje brak refleksji, a wolne mówienie może wytwarzać rodzaj wspólnoty). Gest nieintencjonalny pokazuje, że myślimy, jest naturalny i zgodny z naszym stanem emocjonalnym. Bardzo szybka i bardzo głośna mowa może sprawiać wrażenie, że mówca chce zaatakować odbiorców, mowa cicha sprawia wrażenie sekretu, którym dzieli się mówiący z odbiorcami. Głośna i wolna mowa odbierana może być jako wbijanie gwoździ - bywa bolesne. Trzeba mówić różnie, korzystając z intuicji, która odzwierciedla rzetelne relacje między mówiącym 
a słuchającym, kontekstu sytuacyjnego i tak dalej. W kontekście komunikacji niewerbalnej należy uwzględnić trzy złote zasady:

1. Holistyczność - interpretacja komunikatów niewerbalnych dokonywana jest w sposób nieświadomy. Ważne jest, aby interpretować zespoły gestów, a nie pojedyncze gesty. Generalnie każdy człowiek jest inny i każdy inaczej reaguje na zastane sytuacje społeczne.

2. Spójność - sekwencja spójność znaczeń: postawa, mimika, gesty, dystans i ton. Duże znaczenie ma także spójność pomiędzy wypowiadanymi słowami a towarzyszącymi im gestami.

3. Kontekst - istotne jest uwzględnienie wpływu sytuacji na zachowanie.

Podsumowując, wspomnieć należy, iż komunikowanie jest procesem dynamicznym, ciągłym, zmienia się i rozwija. W procesie tym nadawca jest jednocześnie odbiorcą, a odbiorca nadawcą i to właśnie obie strony są odpowiedzialne za przebieg komunikacji. Spora część komunikacji odbywa się w sposób nieświadomy. Należy zaznaczyć, że często większy udział w odczytywaniu znaczenia komunikatu mają sygnały niewerbalne niż treściowe (Krajewska 2018: 33). Wcześniej omówione aspekty należy uwzględnić również w trakcie analizy zachowań niewerbalnych pomiędzy różnymi pokoleniami - inaczej komunikują się i interpretują swoje stany emocjonalne osoby starsze, odmiennie osoby bardzo młode, zwłaszcza charakteryzujące się wysokimi stopniem posiadanego kapitału ludzkiego. W tym miejscu należy się pochylić nad kwestią zasadności wypracowania właściwych mechanizmów rozpoznawania mowy ciała (gestów, mimiki, postawy) osób komunikujących się w obrębie pracy z podopiecznymi - może to ułatwić pracę przy analizie potrzeb, diagnozowaniu ich stanu czy wskazaniu na stopień ich implementacji.

\section{Właściwa komunikacja międzypokoleniowa i międzykulturowa jako forma wsparcia w pracy socjalnej i polityce społecznej}

Według Mai Sawickiej w społeczeństwach nowoczesnych interakcje w wymiarze współżycia ujęte były w ramy kulturowe, ukształtowane pod wpływem trzech elementów. Pierwszym było istnienie zhierarchizowanej struktury pozycji społecznych, które stanowiły podstawowy układ odniesienia w kształtowaniu „ekonomii szacunku”. Kolejnym było występowanie określonych kodów zachowań, ukształtowanych pod wpływem obowiązujących norm, wartości oraz wychowania, uwarunkowanych przez przynależność do określonej klasy społecznej, wiek i płeć. Trzeci czynnik to „głęboko zinternalizowana i zautomatyzowana samokontrola emocjonalna, wzmacniana przez funkcjonowanie jednostek w relatywnie małych i niezmiennych grupach społecznych" (Sawicka 2018: 59). Obecnie wymienione czynniki ulegają przeobrażeniom na skutek rozbicia systemu pozycji społecznych (zjawisko to bywa określane jako proces demokratyzacji), który polega na zmniejszaniu się dystansów społecznych pomiędzy poszczególnymi segmentami społecznymi, to jest zrównaniu władzy i dostępu do niej; zrównaniu statusów, na podstawie przekonania, że wszyscy ludzie są równi, a zajmowane przez nich pozycje społeczne są wprawdzie zróżnicowane, ale współmierne; tworzeniu 
tak zwanej fasady osobistej przez styl bycia i sposób zachowania (maniery). W związku z wielokulturowością obserwuje się zwielokrotnione możliwości sposobów zachowania się, które często mają nienaturalny charakter (Sawicka 2018: 61).

Właściwa komunikacja międzypokoleniowa jako forma wsparcia w pracy socjalnej i polityce społecznej winna być uwarunkowana wieloma czynnikami. Gdybyśmy zapytali napotkaną na ulicy osobę, co to znaczy dobrze porozumiewać się z innymi, wówczas można by usłyszeć odpowiedzi: to chyba umieć wywierać wpływ, przyciągać ludzi do siebie, zjednywać do swoich racji, to być człowiekiem towarzyskim, z którym interesująco spędza się czas. Cechy te wskazują na osobę, która, jak to określa Mel Silberman i Freda Hansburg, ma talent do ludzi. Jednak chodzi o coś poważniejszego, a mianowicie posiadanie wielopłaszyznowej inteligencji, która nie jest ograniczona jedynie do zdolności politycznych, wywierania wpływu, przekonywania czy uroku osobistego. Wymaga ona różnorodnych umiejętności interpersonalnych i wrażliwości na drugiego człowieka w obszarach takich jak rozumienie innych, czyli zdolność zadawania pytań, słuchania, dostrzegania cudzego punktu widzenia, a więc „,wchodzenia w czyjeś buty”. Należy jasno się wyrażać - konkretnie powiedzieć to, co chce się przekazać; wyzbywać się rozmów na błahe tematy („small talk”), umiejętnie przechodzić do sedna z zachowaniem szczegóów; $\mathrm{w}$ tym przypadku umiejętnie dokonywać sprawdzenia poziomu zrozumienia wypowiedzianych treści. Trzeba zadbać o własne potrzeby, co przejawia się między innymi tym, że stawia się jasne granice i potrafi się w nich poruszać. Należy umieć oddzielić potrzeby od pragnień i dbać o własny komfort psychiczny, chociażby przez niewchodzenie w bliskie relacje z podopiecznymi - wówczas można stracić kontrolę nad emocjami oraz patrzeć na sprawy w sposób subiektywny, zamiast obiektywny i zawodowy. Trzeba zastanowić się nad kwestią wymiany opinii. Utrzymywanie właściwych relacji z innymi, pracowniczych czy przyjacielskich, to umiejętność rychłego skomentowania postępowania innych, tak by interlokutora nie obrazić i nie zranić. Kolejną kwestią jest oddziaływanie na innych. Zwykło się mówić, iż wywieranie wpływu ma jedynie oddźwięk negatywny, jednak może być także odbierane zupełnie inaczej, ponieważ mądre relacje bazujące na wrażliwości, dostrzeganiu potrzeb innych i zaufaniu sprawiają, że można innych motywować, a nie kierować nimi, wskazywać, a nie pokazywać, uczyć przykładem, a nie czynem. Osoba, która posiada zdolność wywierania pozytywnego wpływu na jednostki, grupy i instytucje, jest ceniona i szanowana, w przeciwieństwie do tych, którzy udzielają wielu dobrych rad (niekonstruktywne rady mogą wywołać negatywną reakcję). Cenione są wskazówki szczere i sensowne. Następną cechą jest umiejętność rozwiązywania konfliktów - konflikty zawsze będą towarzyszyły człowiekowi, niezależnie od tego, jaką zajmuje się profesją. W pracy socjalnej konflikty mogą przybierać formę konfliktów zamkniętych, otwartych lub intrapersonalnych, gdy człowiek toczy walkę z własnymi myślami, niejednokrotnie sumieniem, niosąc pomoc bliźniemu w potrzebie. $\mathrm{W}$ takim przypadku należy się zastanowić nad zdolnością rozpoznawania problemu, jego istoty, a nie kształtowania przekonania o rozwiązywaniu konfliktu na podstawie dostępnych technik. Sytuacja mediacyjna może tu być idealnym przykładem: jeśli mediator dąży do załatwienia sprawy bez rozwiązania istoty konfliktu, czyli bez osiągnięcia wzajemnego 
zrozumienia przez uczestników sporu, to wtedy mediacja nie ma sensu. Podobnie sprawa wygląda w przypadku pracowników socjalnych, którzy muszą niejednokrotnie rozwiązywać konflikty z pracownikami, podopiecznymi czy grupami wsparcia. Wymaga to twórczego postępowania. Każdy człowiek jest inny i stosowanie wypracowanych, szablonowych metod poradnikowych w przypadku przynajmniej części konfliktów nie sprawdza się. Należy wypracować własne, indywidualne i sprawdzone sposoby dotarcia do uczestników sporu. Kolejnym elementem jest umiejętność pracy w zespole. Bycie częścią zespołu to wyróżnienie, ale i bardzo trudne zadanie, wymagające poświęcenia, często wiążące się z frustracją czy stresem, jednak relacje budowane na zaufaniu i szacunku mogą sprawić, iż praca w grupie będzie efektywniejsza i przyjemniejsza. Ostatnią cechą jest elastyczność, czyli plastyczność konformistyczna, wymagająca dopasowania sposobów dotarcia do rozmówcy - określa się to jako dostrojenie, poszanowanie „mapy świata” rozmówcy (Silberman, Hansburg 2012: 14-16).

\section{Wnioski końcowe}

Dzięki analizie powyższych pojęć i głównych uwarunkowań dotyczących pracownika socjalnego wysuwają się dwa wnioski. Pierwszy dotyczy kategorii klienta, która pojawia się w trakcie analizy rozmaitych źródeł w tym zakresie. Otóż klient oznacza biorcę usługi, osobę, która jasno i precyzyjnie określa potrzebę bądź lukę w swoim funkcjonowaniu i poszukuje dróg jej zaspokojenia. Zwykle zaspokajanie potrzeb klienta odbywa się odpłatnie. Wówczas realizowane są relacje klient-wykonawca, a nie relacje pracownik socjalny - podopieczny, czyli osoba w potrzebie. Praca socjalna i jej działania to niekoniecznie wykonywanie usług, zatem choć używanie terminu „klient” w pewnych warunkach jest wskazane, to należy unikać jego nadużywania. Drugi wniosek jest taki, że praca socjalna ujęta została jako profesja. Jeśli mówimy o profesji, mamy do czynienia z nieco innym podejściem do wykonywanego zawodu, powinności czy pracy. Tego określenia używamy zazwyczaj wobec zawodów opierających się na powołaniu, zamiłowaniu i pasji, czyli dobrej, nieprzymuszonej woli. Pracownik socjalny wykonuje swój zawód, pracując z klientem, petentem czy beneficjentem, ale nade wszystko z człowiekiem lub na rzecz ludzi.

Pracownik socjalny ma „mówić ludziom”, a nie do ludzi (jeśli chcemy mówić do ludzi, oczekujemy, że będą słyszeli, a nie słuchali). Sformułowanie „mówić ludziom” wskazuje na oczekiwanie, by rozumieli, pojęli i wcielali rady w swoje życie. Takie działanie ma pomagać ludziom. Ma przekazywać komunikat, a nie tylko komunikować się z ludźmi? Z kolei nastawienie na celowość oraz skuteczność komunikowania z podopiecznym może skutkować mniejszą satysfakcją z bycia z kimś, z bycia razem przez mówienie. Rozmowy częściej się obecnie przeprowadza niż prowadzi. Porozumiewanie się powinno być zatem udane, a nie skuteczne - wskazuje wówczas na pierwiastek ludzki (personalistyczne ujęcie człowieka), gdy celem jest między innymi bycie ze sobą. Aktualnie można zauważyć naszpikowanie komunikatów figurami retorycznymi, technikami wywierania wpływu. 
Należy zawrócić uwagę na kształtowanie inteligencji emocjonalnej, czemu służyć mogą rozmaite poradniki czy podręczniki (Segal 1997) w tym zakresie, ale nie zastąpią one wrażliwości ani otwartości na drugiego człowieka, ponieważ XXI wiek należeć będzie do tych, którzy potrafią szybko oduczać się starych i uczyć nowych metod działania. Niezależnie od posiadanej wiedzy, kompetencji miękkich, poziomu wrażliwości czy pewności siebie praca z ludźmi wymaga odpowiedniego sposobu mówienia, dialogu i porozumiewania się - czego dowodem jest profesja pracownika socjalnego. Spotyka on osoby o rozmaitym poziomie ekspresji, wrażliwości i umiejętności racjonalnego analizowania kierowanych do niego słów. Praca z ludźmi w potrzebie wiąże się z wielką odpowiedzialnością za ich zdrowie, sytuację życiową i czasami nawet życie, co dodatkowo nakłada na pracowników socjalnych obowiązek wnikliwej analizy potrzeb oraz oddzielenia ich od pragnień swoich podopiecznych, a nie jedynie realizacji celów określonych przepisami. Zwyczajna rozmowa (dialog), poświęcenie czasu i zwrócenie uwagi na drugiego człowieka, z zachowaniem podstawowych komponentów właściwego, personalistycznego komunikowania, może sprawić, że dana osoba poczuje się ważna, jej komfort psychiczny oraz poczucie własnej wartości się zmieni. Dobrostan psychiczny jednostki niejednokrotnie warunkuje jej zdrowie fizyczne, a na pewno umożliwia powrót do niego. Idea skutecznego komunikowania pomaga, mówiąc językiem prawniczym, rozwiązać sprawę, ale nie gwarantuje zaspokojenia potrzeb życiowych czy dobrostanu psychicznego potrzebującego. Nawiązanie zdrowych i mądrych relacji umożliwi zarówno załatwienie sprawy, jak i pomoc w zakresie psychologicznym jednostce wymagającej pomocy. Człowiek, którego poczucie własnej wartości i dobrostan psychiczny wzrasta, zdecydowanie lepiej radzi sobie z problemami dnia codziennego, wychodząc z trudnych sytuacji materialnych czy chorobowych. Każdy, niezależnie od posiadanej wiedzy, zdrowia czy pozycji społecznej, lubi czuć się dobrze i mieć kontakt z innymi, mieć wokół siebie osoby zaufane, budując tak zwaną kulturę zaufania (Sztompka 2007: 317).

Wykształcenie i utrzymanie właściwego zachowania komunikacyjnego pomiędzy pracownikami socjalnymi a podopiecznymi (biorcami programów pomocowych) wymaga wprowadzania cyklicznych, licznych szkoleń i warsztatów komunikowania społecznego w zakresie mowy ciała, komunikacji niewerbalnej oraz kształtowania kompetencji miękkich, których celem będzie wzmocnienie u pracowników socjalnych potrzeby ciągłej nauki i zrozumienia drugiego człowieka. Takie szkolenia mogą by czasochłonne i kosztowne, ale pozwalają zastąpić część programów pomocowych i skrócić czas interwencji w przeciwdziałaniu wykluczeniu społecznemu dzięki szybszemu zrozumieniu potrzeb ludzi i ich sytuacji życiowej, a także - co szczególnie istotne - wzbudzeniu relacyjności i zabezpieczenia emocjonalnego ludzi w potrzebie. To może wzmocnić ich poczucie własnej wartości, a co za tym idzie, wolę wychodzenia z sytuacji trudnej. Realizacja szkoleń i warsztatów nie powinna być jednorazowa, lecz cykliczna (corocznie), by nie doszło do „uśpienia czujności” i stępienia wrażliwości pracownika socjalnego na potrzeby podopiecznego. Inną kwestią pozostaje sposób rekrutacji pracowników socjalnych do wykonywanej przez nich pracy. Jest to temat trudny ze względu na stosunkowo niskopłatną posadę, niewarunkującą właściwej postawy względem podnoszenia kwalifikacji. 
Odmiennym problemem jest dobór (rekrutacja) odpowiednich osób, które przejawiają cechy wskazujące na osobę zdolną do pracy z człowiekiem wymagającym uwagi oraz pomocy, a więc pracy, która powinna stać się powołaniem, a nie zawodem.

\section{Bibliografia}

Buller L.J. (2005). Bezpieczne i skuteczne komunikowanie. Praktyczny poradnik postępowania. Wydawnictwo Diecezjalne Sandomierz, Warszawa.

Buller L.J. (2008). Influencja. Wydawnictwo Katolickiego Uniwersytetu Lubelskiego Jana Pawła II, Stalowa Wola.

Frydrychowicz S. (2005). Sposoby i wymiary komunikowania interpersonalnego a rozwój człowieka. „Psychologia Rozwojowa”, 10 (3): 93-100.

Garvin Ch.D., Seabury B.A. (1998a). Działania interpersonalne w pracy socjalnej. Procesy i procedury, cz. 1, tłum. J. Banasiak. Biblioteka Pracownika Socjalnego, Katowice.

Garvin Ch.D., Seabury B.A. (1998b). Działania interpersonalne w pracy socjalnej. Procesy i procedury, cz. 2, tłum. J. Banasiak. Biblioteka Pracownika Socjalnego, Katowice.

Krajewska A. (2018). Kompetencje personalne i społeczne. Wydawnictwo Ekonomik - Jacek Musiałkiewicz, Warszawa.

Pisarek W. (2008). Wstęp do nauki o komunikowaniu. Wydawnictwo Akademickie i Profesjonalne, Warszawa.

Plęs A. (2019). Prof. Jerzy Bralczyk: Jak mówić, żeby nas stuchano? Nie ma jednej metody; https:// plus.nowiny24.pl/prof-jerzy-bralczyk-jak-mowic-zeby-nas-sluchano-nie-ma-jednej-metody/ ar/12008317 (dostęp: 1.11.2019).

Sawicka M. (2018). Emocje w interakcjach współczesnego społeczeństwa polskiego. Wydawnictwo Uniwersytetu Warszawskiego, Warszawa.

Segal J. (1997). Jak pogłębić inteligencję emocjonalną, tłum. M. Jałocho, P. Kołyszko, I. Szyszkowska-Andruszko. Wydawnictwo Jacek Santorski \& CO, Warszawa.

Silberman M., Hansburg F. (2012). Inteligencja interpersonalna. Jak utrzymać mądre relacje $z$ innymi, tłum. D. Piotrowska. Wydawnictwo Studio EMKA, Łódź.

Sztompka P. (2007). Socjologia. Analiza społeczeństwa. Wydawnictwo Znak, Kraków. 